\title{
Nonlinear Real Exchange Rate Dynamics and Oil Prices in the Commonwealth of Independent States
}

\author{
Ph.D. Candidate Nezahat Küçük (Eastern Mediterranean University, Cyprus)
}

\begin{abstract}
This paper investigates the role of country specific and global factors, particularly oil price, on the real exchange rate (RER) in selected Commonwealth of Independent States (CIS) countries (Azerbaijan, Kazakhstan, Kyrgyzstan, Moldova, Russia, Turkmenistan, Ukraine, and Uzbekistan) over the period from 2000 to 2011. The group of higher income, lower income, oil and gas exporter, and non- oil and gas exporter countries are further analyzed separately to induce homogeneity. The analysis is based on panel smooth transition autoregressive (PSTR) model, which takes into account the nonlinear dynamic adjustment of the real exchange rate towards equilibrium. The estimation results show strong nonlinear dynamic adjustment for the real exchange rate. Upon obtaining strong evidence on nonlinear dynamic behavior, which is modeled using a smooth transition autoregressive model with two regimes, we test the impact of global and country specific drivers on the real exchange rate. As an extension, panel smooth transition error correction model is estimated. Results show that there exists an asymmetric behavior of the real exchange rate when facing an over- or undervaluation of the domestic currency. The evidence also shows that oil price has significant impact for the appreciation of domestic currencies, particularly in oil and gas exporting relatively richer countries, and the CIS countries have become vulnerable to global shocks.
\end{abstract}

JEL codes: F31, C22, G15

\section{Introduction}

This study investigates the dynamics of real exchange rate and role of global and country specific factors for some of the selected CIS economies (Azerbaijan, Kazakhstan, Kyrgyzstan, Moldova, Russia, Turkmenistan, Ukraine, and Uzbekistan). In order to have a more homogenous grouping four groups as higher income (Russia, Kazakhstan, and Ukraine), lower income (Azerbaijan, Kyrgyzstan, Moldova, Turkmenistan, and Uzbekistan), major oil and gas exporter (Azerbaijan, Kazakhstan, Russia, Turkmenistan), and non- oil and gas exporter (Kyrgyzstan, Moldova, Ukraine, and Uzbekistan). Some of the CIS economies considered in this study, namely Azerbaijan, Kazakhstan, Russia, Turkmenistan and Uzbekistan, achieved rapid economic growth since early 2000s. It is clear that the economic growth in these economies stems mainly from the expansion in oil and natural gas sectors. Since natural gas is secondary in terms its size and oil dominates the energy exports in CIS countries, this study only considers oil as a proxy for natural resource exports. Oil extraction and exports, but also the oil revenues in these selected CIS economies, will rise due to increase in oil prices in world markets. This is a significant and non-ignorable impact on the macroeconomic performance of counties like Azerbaijan, Kazakhstan, Russia, Turkmenistan and Uzbekistan.

The relationships between exchange rate and oil prices were examined in the literature in a number of studies. It is commonly expected that real shocks have significant and major impact on real exchange rate fluctuations, especially for small open economies. Moreover, changes in these variables may affect international trade, financial markets, and price of some other commodities because oil is the major input for production in major sectors. This paper uses the case of CIS countries (Azerbaijan, Kazakhstan, Kyrgyzstan, Moldova, Russia, Turkmenistan, Ukraine, and Uzbekistan) over the period from 2000 to 2011 in order examine the impact of oil prices on the real exchange rate by a nonlinear specification of the real exchanger rate dynamics.

The revenue from oil and gas exports is a significant and non-ignorable impact on the macroeconomic performance of counties like Azerbaijan, Kazakhstan, Russia, Turkmenistan, and Uzbekistan. For example, Azerbaijan had a record rate of $34.5 \%$ gross domestic product (GDP) growth in 2006, which was mainly due to rising oil prices and oil exports. The CIS countries also experienced hyperinflation periods, weakening the exchange rate competitiveness, while sustainable oil export expansion brought appreciation forces, particularly in oil exporting countries such as Azerbaijan and Kazakhstan. There are reasons to believe that the appreciation of the domestic currencies may be closely related to oil exports and oil prices. Thus, CIS countries form an interesting case to study the real exchange rate dynamics and due to steady prevalence hyperinflation and oil price changes.

The study is motivated from two three observations. First, the concept of the resource curse, especially for the real exchange rate appreciation and Dutch disease phenomenon predicts some strong connection between oil price and real exchange rate (RER) appreciation (Corden and Neary, 1982; Corden, 1984; Wijnbergen, 1984; Buiter and Purvis, 1982; Bruno and Sachs, 1982; Enders and Herberg, 1983; Edwards, 1985). Second, several studies found a significant relation between the RER and the price of oil in oil-exporting countries, such as Koranchelian (2005) in Algeria, Zalduendo (2006) in Venezuela, Issa et al. (2006) in Canada, Habib and Kalamova (2007) in Norway, Saudi Arabia and Russia, Oomes and Kalcheva (2007) in Russia, Korhonen and 
Juurikkala (2009) in nine OPEC countries, and Jahan-Parvar and Mohammadi (2008) in fourteen oil-exporting countries. Third, oil revenues in most oil exporting countries are majorly spent on non-tradable sectors of the economy as budget expenditures. Relatively high expenditures on the non-tradable sector, therefore, produce higher relative prices for non-tradable goods, leading to higher inflation rates. Furthermore, the supply of foreign currency in excess of the revenues leads to the nominal exchange rate appreciation. As a result, the relative increase in prices and nominal exchange rate appreciation are the two channels of real exchange rate appreciation.

Thus, based on the theoretical framework of Dutch Disease, this study investigates the RER dynamics in CIS countries. Different form the previous literature, we us a panel data approach and incorporate the nonlinear adjustment of real exchange rate as against the linear models used in previous studies. The study shows that the real exchange rate in CIS countries follows a nonlinear adjustment process towards the equilibrium, which is modeled by a dynamic panel smooth transition (PSTR) regression specification. Other determinants of the equilibrium exchange rate are also taken into account in the study. These include terms of trade, net foreign assets, productivity, and real government expenditure. The study finds a strong statistically significant positive relationship between the real oil price and real exchange rare appreciation. The results of the study are useful for policymakers in terms of managing the oil revenues and designing right exchange rate policies.

The rest of the paper is organized as follows. Section 2 introduces the existing literature and theory. Section 3 explains the empirical model and estimation methodology. Section 4 describes the data and discuses the estimation results. Section 5 concludes the paper.

\section{Theory and Literature}

A number of studies in the literature suggested that the movements in oil prices have direct or indirect effect on financial and economical activities, and additionally, its impact is expected to be different for oil exporting or oil importing countries. When oil prices increases, this will cause progressive impact on the economy or financial markets of the oil exporting country, however, the result of increased oil prices will cause negative effect on the economy of an oil importing country. When we consider the oil as a basic input for production, any price change in oil price will work as a supply side shock in the economy.

In addition to oil price, this paper analyses the interaction of oil prices and real exchange rate as well. Real exchange rate can be defined as the relative price of domestic currency with respect to the foreign currency while considering the inflation differentials among countries. Real exchange rate is one of the most important indicators for the country's foreign trade. Any fluctuation in real exchange rate will lead fluctuations in financial markets as well, due to its significant and impact on capital flow across countries. Economic theories indicate that any depreciation of real exchange rate of a country will lead to an increase in exports and decrease in imports. This will encourage capital inflow from to oil importing countries where exchange rate depreciates, and outflow from oil exporting countries where exchange rate appreciates. Therefore, real exchange rate and oil price are important from both theoretical and practical points particularly for those countries who receives significant revenue from oil exports.

Chaudhuri and Daniel (1998) analyses the real exchange rate and oil prices for sixteen OECD countries during 1973-1996 by using augmented Dickey-Fuller (ADF) unit root tests, Granger-Causality tests. They further specify an error correction model (ECM) that captures the long-run relationship between real echange rate and its determinants. They found that oil prices are weakly endogenous while real exchange rate is not, which means the reasons of non-stationary of real exchange rate movements are due to non-stationary real oil price movements. A similar conclusion was made by Amano and Norden (1998). Amano and Norden (1998) used monthly data from 1972 to 1993 for Germany, US, and Japan to analyze the co-integration of real effective exchange rate and real oil price, and then the direction of causality between these series. They found that an increase in the real oil price would cause appreciation of the real exchange rate in the long run, and found no opposite causality which means real exchange rate does not cause fluctuations in oil price. Another study by Akram (2004) for Norway, which is the one of major oil exporter in the World, by using daily data from January 1986 to August (1998) found that non-linear negative relationship between crude oil prices and Norwegian exchange rate. Akram also concluded that oil price movements in short run has much more significant effects on the Norway's economy than its effect in long run. Same conclusion for Norway was made by Bergvall (2004). Bergvall analyzed Scandinavian countries, including Norway, using data for the 1975-2001 period and found that when real oil price decreases, real exchange rate decreases as well for Swedish, Danish, and Finish economies, which are all oil importer countries. However, for the case of Norway, which is a major oil exporter country, an increase in oil price lowers the exchange rate of Norwegian due to the improvements in terms of trade. Chen and Chen (2007) analyzed the long-run relationship between reel exchange rate and reel oil prices in G7 countries by using monthly panel data between 1972 and 2005. Chen and Chen (2007) used different oil price data in their analyses such as the World price, United Arab Emirates price, British price, and US West Texas Intermediate price of oil. According to their country based analyses results, real exchange rate and real oil prices are co- 
integrated only for two countries. Then, they used panel co-integration tests by pooling all countries to increase the power of unit root and cointegration tests, and they found robust results with resepct to the various oil price series used in the study. Finally, according to their panel regression results both in the short-run and long-run, real oil prices have significant predictive power. We should emphasize that all most of these studies in the literature concentrated on developed countries and evidence on developing and emerging economies is yet limited.

On the other hand, some studies found opposite direction of causality between reel exchange rate and oil prices. In the case of OPEC members, Cooper (1994) found that movements in the oil prices in the short-run were caused due to the movements in exchange rates in 1980s. In the case of large industrial economies, Brown and Philips (1986) found that appreciation of the dollar decreased oil price by 20 percent in 1984 than if there was no appreciation. Another study by Rautava (2004), examined the impact of real exchange rate and oil prices on Russia's economy by using quarterly data from 1995 to 2002, and using co-integration analyses in order to build vector error correction (VEC) model. Rautava (2004) concluded that both oil price and real exchange rate affect Russia's economy in terms of output and fiscal revenues without stating the direction of causality. A study by Krichene (2005), using monthly, quarterly, and annual frequency data to analyze the relationship between oil prices, exchange rates, and interest rates concluded that co-integration coefficients changes in signs and significance due to frequency of data, sample, and number of lags. Korhonen and Mehrotra (2009), who used structural vector autoregression (VAR) model to examine the effects of oil price shock on real exchange rates and output in Iran, Kazakhstan, Venezuela, and Russia, which are large energy producers, found higher oil price is associated with higher output, and oil shocks do not account for a large share of movements in the real exchange rate, although its significance is higher for Venezuela and Iran.

Most studies investigating the links between reel exchange rate and oil prices motivated from Dutch Disease phenomena. According to the Dutch Disease phenomena, shocks to booming sector (natural resource rich sectors such as oil) leading to increases in its price will lead more investment in this sector. In turn, more labor is needed in this sector to produce more output, and this causes labor shift from agricultural and manufacturing sector to booming sector. As a result, competitiveness and exports of other sectors will decrease. At the same time, increased labor demand in booming sector will place an upward pressure in wages. Then, an increase in wages and price of non-tradable goods in terms of tradable will cause an appreciation of real exchange rate of the country. Based on the result of the studies discussed above, one can say that oil producer and oil exporting countries may have different reaction to changes in oil prices, and also exchange rate can be an effective policy instrument, especially in oil producing countries, particularly there is a no strong causal nexus from oil price to exchange rate.

This paper contributes in two ways to the existing literature. First, we analyze the relationship between oil price and real exchange rate in selected CIS countries (Azerbaijan, Kazakhstan, Kyrgyzstan, Moldova, Russia, Turkmenistan, Ukraine, and Uzbekistan) over the period from 2000 to 2011. This countries with their volatile history of exchange rate and oil exporting and oil importing structures form an interesting case study to examine the links between oil prices and exchange rates. Second, we use a panel smooth transition autoregressive (PSTR) model, which takes into account of the nonlinear dynamic adjustment of the real exchange rate towards its equilibrium. This is a more accurate formulization of the exchange rates movements, which is less likely to lead to incorrect inferences.

\section{Methodology}

Most studies on real exchange rate in emerging economies are based on the equilibrium real exchange rate model following the studies by Edwards (1994), Elbadawi (1994), and Hinkle and Montiel (1999). Some studies deal more specifically with the dynamics. These models, developed for the industrialized economies, highlights the role played by fundamental variables in the determination of equilibrium exchange rates. The models constructed for developing economies take account of various aspects of general equilibrium real exchange rate determination in emerging markets and includes some additional fundamental variables absent from the models developed for industrialized countries.

An equilibrium real exchange rate model, describing the value of long-term equilibrium real exchange rate can include several factors that determines the equilibrium value of RER: productivity differential in favor of the tradable sector, public expenditure on non-tradable and tradable goods, the foreign inflation rate, real interest rate, and net foreign balance of international transfers. Additionally, models for emerging markets may include variables such as the terms of trade, net foreign assets, openness, etc. We additionally include real oil prices to account for the Dutch disease phenomena to account for the impact of oil prices in oil exporting countries in our sample. Although, the Dutch disease would be more likely to exist for oil exporting countries, the CIS countries on our sample are so much linked to each other that the impact of oil prices may be common to all of them.

We specify a long-run equation for the real effective exchange rate (REER), which is also called behavioral exchange rate model, incorporating particular variables that are significant determinants of the REER in CIS 
countries. In this context, the REER equation, which is a solution for a long-run level of the real exchange rate in terms of the economic fundamentals that determine the long-run value of the real exchange rate, is specified as follows:

$$
\text { LREER }_{i t}={ }_{i}+{ }_{1} \text { LTOT }_{i t}+{ }_{2} \text { LPROD }_{i t}+{ }_{3} \text { LOPEN }_{i t}+{ }_{4} L_{\text {GOVREAL }}+{ }_{5} \mathrm{NFA}_{i t}+{ }_{6} \text { LOIL }_{i t}+{ }_{i t}
$$

Here, $i$ and $t$ represent country and time indices, respectively, $\alpha_{i}$, and $\varepsilon_{i t}$ are country-specific intercepts and error terms, LREER denotes logarithm of the real effective exchange rate, LTOT denoted logarithm of terms of trade, $L P R O D$ denotes logarithm of relative productivity per person, $L O P E N$ denotes logarithm of the degree of openness, LGOVREAL denotes logarithm of public spending relative to GDP, and NFA denotes logarithm of net foreign assets relative to GDP, and LOIL denotes the real price of crude oil.

The long-run equilibrium relation in equation (1) is estimated using panel cointegration estimation since all variables are established to be non-stationary, i.e., posses unit roots. After estimating the long-run relationship, we specify and estimate the following linear Error Correction Model (ECM):

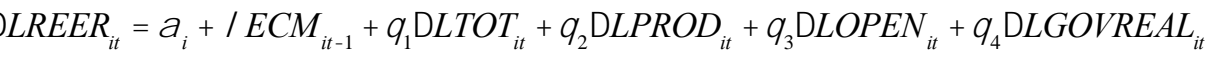

$$
\begin{aligned}
& +{ }_{5} \mathrm{NFA}_{i t}+{ }_{6} \mathrm{LOIL}_{i t}+v_{i t}
\end{aligned}
$$

where

$$
E C M_{i t}=\text { LREER }_{i t} \quad{ }_{i} \quad{ }_{1} L T O T_{i t} \quad{ }_{2} \text { LPROD }_{i t} \quad{ }_{3} \text { LOPEN }_{i t} \quad{ }_{4} \text { LGOVREAL }_{i t} \quad{ }_{5} \text { NFA }_{i t} \quad{ }_{6} \text { LOIL }_{i t}
$$

The endogeneity of the REER in (2) is tested and parameters are estimated using the generalized method of moments (GMM). As the coefficient associated with the lagged REER variable was not significant, GMM estimates are not retained and the vector ECM (VECM) is estimated using the within estimator.

To capture the potential nonlinearity in the adjustment process of the real exchange rate towards its long-run equilibrium, we use a Panel Smooth Transition Regression (PSTR) model (González et al., 2005). This model allows different dynamics in distinct regimes, identified by a threshold value. Likely regimes are crises and expansion, or appreciation and depreciation, which are separated by the value of the equilibrium error $E C T_{i t}$. In the PSTR model, the transition from one regime to another is smooth or gradual, possibly due to transaction costs, uncertainty, rigidity, bubbles, etc. The PSTR model with two regimes can be formulated as follows:

$$
R E E R_{i t}={ }_{i}+{ }_{1}^{\prime} x_{i t}+{ }_{2}^{\prime} x_{i t} F\left(E C M_{i t d},, c\right)+u_{i t}
$$

where $F($.$) is the transition function controlling the regime shift mechanism and is a smooth and continuous$ function of past realized deviations from the equilibrium. Thus, real exchange rate changes evolve with a smooth transition between regimes that depends on the sign and magnitude of past realization of the deviations from the equilibrium. The non-linearity is formulated by conditioning the coefficients, ${ }_{1}$ and ${ }_{2}$, to change smoothly with past equilibrium errors in such a way that the past realized equilibrium errors $E C M_{i t ~} d$ is the transition variable with $d$ being the delay parameter, which, in turn, indicates the number of periods $E C M_{i t} d$ leads the switch in dynamics.

Teräsvirta and Anderson (1992) define the transition function $F($.$) by using two alternative forms, namely the$ logistic smooth transition autoregressive (LSTAR) model and the exponential smooth transition autoregressive (ESTAR) model. In the LSTAR model, which is used in this study, $F($.$) is defined by a logistic function, so that:$

$$
F\left(E C M_{i t d}, \quad, c\right)=\left[1+\exp \left\{\quad\left(E C M_{i t d} c\right\}\right]^{1}, \quad>0\right.
$$

where $c$ is the threshold value separating two regimes. We favor LSTAR both based on statistical tests and because it allows an asymmetric adjustment speed across different regimes, whereas ESTAR has a symettric adjustment structure in different regimes. Once the nonlinearity is established, we proceed and estimate the following Panel Smooth Transition Error Correction Model (PSECM):

$$
\begin{aligned}
\text { LREER }_{i t} & ={ }_{i}+\left[{ }^{1} \text { ECM }_{i t d}+{ }_{1}^{1} \text { LTOT }_{i t}+{ }_{2}^{1} \text { LPROD }_{i t}+{ }_{3}^{1} \text { LOPEN }_{i t}+{ }_{4}^{1} \text { LGOVREAL }_{i t}\right. \\
& \left.+{ }_{5}^{1} \text { NFA }_{i t}+{ }_{6}^{1} \text { LOIL }_{i t}\right]+\left[{ }^{2} \text { ECM }_{i t d}+{ }_{1}^{2} \text { LTOT }_{i t}+{ }_{2}^{2} \text { LPROD }_{i t}+{ }_{3}^{2} \text { LOPEN }_{i t}\right. \\
& \left.+{ }_{4}^{2} \text { LGOVREAL }_{i t}+{ }_{5}^{2} \text { NFA }_{i t}+{ }_{6}^{2} \text { LOIL }_{i t}\right] \times F\left(E_{\text {CCM }}, \quad, c\right)+u_{i t}
\end{aligned}
$$

The estimation of the PSECM given in Equation (6) can be carried out in the nature of fixed effects estimation, which consists of demeaning the variables using country specific means before moving to the nonlinear estimation of the remaining parameters. 


\section{Data and Empirical Results}

The dataset used in the study contains panel observations on selected CIS countries, Azerbaijan, Kazakhstan, Kyrgyzstan, Moldova, Russia, Turkmenistan, Ukraine, and Uzbekistan over the period from 2000 to 2011. The analyses are carried for full set of above eight countries and also for four subgroups of these countries. First, we divide the sample into two subgroups based on the per capita real GDP. The higher income group contains Kazakhstan, Russia, Turkmenistan, Ukraine, which have per capita real GDP above 3500 US dollars in 2011, and lower income group contains Azerbaijan, Kyrgyzstan, Moldova, Turkmenistan, and Uzbekistan. Since oil and gas exporting and oil and gas importing countries may have different real exchange rate dynamics in terms of the response of real exchange rate to oil price, we form two other groups based on oil and gas exports. First group is the major oil and gas exporters and includes Azerbaijan, Kazakhstan, Russia, and Turkmenistan, and the second group is the non- oil and gas exporter formed by Kyrgyzstan, Moldova, Ukraine, and Uzbekistan. The data used in the study is obtained from various sources. The data on crude oil prices is the spot price of West Texas Intermediate crude at Cushing obtained from DataStream ad deflated by the US Consumer Price Index. Rest of the data is obtained from the World Bank's World Development Indicators and European Bank for Reconstruction and Development (EBRD) Transition Economies Database.

A preliminary and crucial step in dynamic analysis of the time series is to reveal the stationarity properties of the underlying time series. In order to discover the stationarity properties of the data we perform several panel unit root tests. The results of the unit root tests are given in Table 1. All the unit root tests we have performed indicate that all variables do have unit root in levels and stationary in first differences, except two exception where one test indicates LREER and LGOVREAL might be stationary, which is ignored since majority of the tests indicates the opposite. Thus, the series are integrated of order one and whether they maintain a long-run equilibrium should be investigated by panel cointegration tests.

\begin{tabular}{|c|c|c|c|c|}
\hline Level: & $\mathbf{L L C}^{\mathbf{a}}$ & IPS $^{\mathbf{b}}$ & ADF-F ${ }^{c}$ & PP-F ${ }^{d}$ \\
\hline LREER & $-1.104[0.135]$ & $2.042[0.979]$ & $7.358[0.966]$ & $6.035[0.988]$ \\
\hline LTOT & $-1.465[0.072]$ & $1.013[0.844]$ & $6.674[0.979]$ & $5.703[0.991]$ \\
\hline LOPEN & $-2.742[0.003]^{* * * *}$ & $-1.159[0.123]$ & $22.806[0.119]$ & $20.108[0.216]$ \\
\hline LGOVREAL & $1.009[0.844]$ & $1.974[0.976]$ & $11.254[0.794]$ & $35.637[0.003]^{* * * *}$ \\
\hline NFA & 1.547 [0.939] & $4.055[1.000]$ & $5.459[0.993]$ & $3.442[0.999]$ \\
\hline LPROD & $2.422[0.992]$ & $3.901[1.000]$ & 6.661 [0.979] & $5.651[0.992]$ \\
\hline LOIL & $-1.461[0.072]$ & $1.023[0.847]$ & $6.639[0.979]$ & $5.586[0.992]$ \\
\hline \multicolumn{5}{|c|}{ First Difference: } \\
\hline LREER & $-4.147[0.000]^{* * * *}$ & $-3.620[0.000]^{* * * *}$ & $39.834[0.001]^{* * * *}$ & $42.821[0.000]^{* * * *}$ \\
\hline LTOT & $-19.950[0.000]^{* * *}$ & $-8.997[0.000]^{* * * *}$ & $90.911[0.000]^{* * * *}$ & $106.584[0.000]^{* * *}$ \\
\hline LOPEN & $-7.672[0.000]^{* * *}$ & $-6.510[0.000]^{* * *}$ & $67.564[0.000]^{* * *}$ & $56.377[0.000]^{* * * *}$ \\
\hline LGOVREAL & $-9.053[0.000]^{* * *}$ & $-6.452[0.000]^{* * * *}$ & $63.204[0.000]^{* * *}$ & $90.284[0.000]^{* * * *}$ \\
\hline NFA & $-2.562[0.005]^{* *}$ & $-3.950[0.000]^{\text {**** }}$ & $57.379[0.000]^{* * *}$ & $49.682[0.000]^{* * * *}$ \\
\hline LPROD & $-2.559[0.005]^{* *}$ & $-3.602[0.000]^{\text {**** }}$ & $40.284[0.001]^{* * *}$ & $34.473[0.005]^{\text {** }}$ \\
\hline LOIL & $-9.950[0.000]^{* * *}$ & $-4.162[0.000]^{* * * *}$ & $44.509[0.000]^{* * *}$ & $96.459[0.000]^{* * * *}$ \\
\hline \multicolumn{5}{|c|}{$\begin{array}{l}\text { Notes: Test equation includes on reference. Lag-length is chosen by the Shwarz Information Criteria. Same tests are performed for higher } \\
\text { income, lower income, oil and gas exporters and non- oil and gas exporters groups. The results are analogous and not reported to save space, } \\
\text { but available from the author. } \\
\text { a Levin, Lin and Chu (2002) panel unit root test. }{ }^{\text {b }} \text { Im, Peseran and Shin (2003) panel unit root test. }{ }^{\text {c }} \text { Fisher Type Test-using ADF and d } \\
\text { Fisher Type Test-using PP (Maddala and Wu (1999) and Choi (2001)), and Hadri (2000). }\end{array}$} \\
\hline
\end{tabular}

Table 1. Panel Unit Root Tests

The existence of a cointegration relationship between the REER and its fundamental determinants is tested by using firstly the now well-known Pedroni $(1999,2004)$ tests. We additionally perform more recent tests developed by Westerlund (2007, 2008), which are similar to Engle and Granger (1987) test for time series data. The cointegration test results are reported in Table 2. According to the results presented in Table 2, the null hypothesis of no cointegration is rejected by the Westerlund test for all group of countries. Results of the Westerlund and Edgerton test also lead to indicate existence of a cointegration relationship for the panel as a whole. Finally, first and second-generation cointegration tests reported in Table 2 provide additional evidence in favor of a long-run cointegration relationship between the real exchange rate and its fundamentals for all country groups we consider.

From the cointegration analysis we conclude that the real exchange rates in CIS show a convergence process to their long-run levels. However, this result is based on a linear model. In order to investigate the validity of linear dynamics, we check the presence of nonlinearities in the real exchange rate adjustment process.

In Table 3, we report the nonlinearity tests as well as no remaining nonlinearity test. The tests results clearly select a 2-regime nonlinear model over a linear model for five group of countries unanimously. Furthermore, the residuals of the PST model do not show any remaining nonlinearity, implying that PST model sufficiently 
captures the nonlinearity in the real exchanger rate series for CIS countries and their four sub-groups studied in this paper.

After establishing the nonlinear adjustment process for the real exchange rate series of the CIS countries, we estimate the Panel Smooth Transitions Error Correction model. The nonlinear regression estimates and asymptotic standard errors of the estimates are given in Table 4. The nonlinear ECM estimates reveal answers to questions raised before in the study.

\begin{tabular}{|c|c|c|c|c|c|c|}
\hline Tests $^{\mathrm{a}}$ & Statistics & $\begin{array}{l}\text { All } \\
\text { Countries }\end{array}$ & $\begin{array}{l}\text { Higher } \\
\text { Income }\end{array}$ & $\begin{array}{l}\text { Lower } \\
\text { Income }\end{array}$ & $\begin{array}{l}\text { Oil and } \\
\text { Gas } \\
\text { Exporter }\end{array}$ & $\begin{array}{l}\text { Non- } \\
\text { Oil-Gas } \\
\text { Exporter }\end{array}$ \\
\hline \multirow[t]{2}{*}{$\begin{array}{l}\text { Westerlund (with one } \\
\text { factor) }\end{array}$} & $\mathrm{DH}_{\mathrm{g}}$ & $\begin{array}{l}37.88^{* * * *} \\
(0.00)\end{array}$ & $\begin{array}{l}29.88^{* * * *} \\
(0.00)\end{array}$ & $\begin{array}{l}26.75^{* * * *} \\
(0.00)\end{array}$ & $\begin{array}{l}33.34^{* * * *} \\
(0.00)\end{array}$ & $\begin{array}{l}30.23^{* * * * *} \\
(0.00)\end{array}$ \\
\hline & $\mathrm{DH}_{\mathrm{p}}$ & $\begin{array}{l}29.07^{* * *} \\
(0.00)\end{array}$ & $\begin{array}{l}24.90^{* * * *} \\
(0.00)\end{array}$ & $\begin{array}{l}22.70^{* * *} \\
(0.00)\end{array}$ & $\begin{array}{l}29.51^{* * * *} \\
(0.00)\end{array}$ & $\begin{array}{l}17.72^{* * *} \\
(0.00)\end{array}$ \\
\hline \multirow[t]{2}{*}{$\begin{array}{l}\text { Westerlund (with eight } \\
\text { factors) }\end{array}$} & $\mathrm{DH}_{\mathrm{g}}$ & $\begin{array}{l}17.56^{* * *} \\
(0.00)\end{array}$ & $\begin{array}{l}18.70^{* * *} \\
(0.00)\end{array}$ & $\begin{array}{l}6.65 \\
(0.12)\end{array}$ & $\begin{array}{l}20.98^{* * *} \\
(0.00)\end{array}$ & $\begin{array}{l}8.82^{*} \\
(0.06)\end{array}$ \\
\hline & $\mathrm{DH}_{\mathrm{p}}$ & $\begin{array}{l}16.63^{* * * *} \\
(0.00)\end{array}$ & $\begin{array}{l}18.29^{* * *} \\
(0.00)\end{array}$ & $\begin{array}{l}10.67^{* * *} \\
(0.00)\end{array}$ & $\begin{array}{l}17.07^{* * *} \\
(0.00)\end{array}$ & $\begin{array}{l}10.35^{* * *} \\
(0.00)\end{array}$ \\
\hline \multirow[t]{2}{*}{$\begin{array}{l}\text { Westerlund and Edgerton } \\
\text { (constant only) }\end{array}$} & $\mathrm{LM}_{+}$ & $\begin{array}{l}48.12^{* * *} \\
(0.00)\end{array}$ & $\begin{array}{l}48.38^{* * *} \\
(0.00)\end{array}$ & $\begin{array}{l}33.99^{* * *} \\
(0.00)\end{array}$ & $\begin{array}{l}51.07^{* * *} \\
(0.00)\end{array}$ & $\begin{array}{l}36.73^{* * *} \\
(0.00)\end{array}$ \\
\hline & $\mathrm{LM}_{\mathrm{n}}$ & $\begin{array}{l}35.28^{* * *} \\
(0.00)\end{array}$ & $\begin{array}{l}33.65^{* * *} \\
(0.00)\end{array}$ & $\begin{array}{l}25.70^{* * *} \\
(0.00)\end{array}$ & $\begin{array}{l}31.19^{* * *} \\
(0.00)\end{array}$ & $\begin{array}{l}21.87^{* * *} \\
(0.00)\end{array}$ \\
\hline \multirow[t]{13}{*}{ Pedroni } & v-Statistic Panel & $\begin{array}{l}-5.48^{* * * *} \\
(0.00)\end{array}$ & $\begin{array}{l}-6.49^{* * *} \\
(0.00)\end{array}$ & $\begin{array}{l}-3.11^{* * *} \\
(0.04)\end{array}$ & $\begin{array}{l}-5.52^{\text {**** }} \\
(0.00)\end{array}$ & $\begin{array}{l}-2.00^{*} \\
(0.08)\end{array}$ \\
\hline & rho-Statistic & $8.13^{* * * *}$ & $2.57^{*}$ & $2.27^{*}$ & $3.43^{* * * *}$ & $2.72^{* * * *}$ \\
\hline & Panel & $(0.00)$ & $(0.08)$ & (0.09) & $(0.00)$ & $(0.08)$ \\
\hline & PP-Statistic & $-3.21^{* *}$ & $-2.65^{*}$ & $-2.02^{*}$ & $-3.18^{* * *}$ & -1.41 \\
\hline & Panel & $(0.03)$ & $(0.07)$ & (0.09) & $(0.03)$ & $(0.17)$ \\
\hline & ADF-Statistic & $-1.56^{*}$ & $-4.00^{* * * *}$ & -1.15 & $-3.05^{* * *}$ & $-1.06^{* * * *}$ \\
\hline & Panel & $(0.07)$ & $(0.00)$ & $(0.16)$ & $(0.02)$ & $(0.19)$ \\
\hline & rho-Statistic & $6.40^{* * * *}$ & $-4.86^{* * * *}$ & 1.18 & $7.55^{* * * *}$ & $3.26^{* *}$ \\
\hline & Group & $(0.00)$ & $(0.00)$ & $(0.00)$ & $(0.00)$ & $(0.04)$ \\
\hline & PP-Statistic & $-7.62^{* * *}$ & $-6.12^{* * *}$ & $-5.63^{* * *}$ & $-7.55^{* * *}$ & $-6.30^{* * *}$ \\
\hline & Group & $(0.00)$ & $(0.00)$ & $(0.00)$ & $(0.00)$ & $(0.00)$ \\
\hline & ADF-Statistic & $-6.69^{* * *}$ & $-4.69^{* * *}$ & $-3.97^{* * *}$ & $-5.70^{* * * *}$ & -3.72 \\
\hline & Group & $(0.00)$ & $(0.00)$ & $(0.04)$ & $(0.00)$ & $(0.04)$ \\
\hline
\end{tabular}

hypothesis of no cointegration at the $10 \%, 5 \%$ and $1 \%$ significance level, respectively.

Table 2. Panel Cointegration Tests

\begin{tabular}{|c|c|c|c|c|c|}
\hline Hypothesis & All Countries & $\begin{array}{l}\text { Higher } \\
\text { Income }\end{array}$ & $\begin{array}{l}\text { Lower } \\
\text { Income }\end{array}$ & $\begin{array}{l}\text { Oil and } \\
\text { Gas } \\
\text { Exporter }\end{array}$ & $\begin{array}{c}\text { Non- Oil- } \\
\text { Gas } \\
\text { Exporter }\end{array}$ \\
\hline $\mathrm{H}_{0}: r=0$ versus $\mathrm{H}_{1}: r=1$ & $6.49(0.00)$ & $6.49(0.00)$ & $6.49(0.00)$ & $6.49(0.00)$ & $6.49(0.00)$ \\
\hline $\mathrm{H}_{0}: r=0$ versus $\mathrm{H}_{1}: r=1$ & $1.23(0.42)$ & $1.23(0.42)$ & $1.23(0.42)$ & $1.23(0.42)$ & $1.23(0.42)$ \\
\hline
\end{tabular}

Table 3. Fisher-LM Linearity and No Remaining Nonlinearity Tests

The estimates in Table 4 show that the adjustment of the REER process is highly asymmetric across all country groups. However, there are significant differences across the groups. The results show that the shocks to the RER is more persistent in the higher income and oil and gas exporting countries, indicating that the impact of oil shocks would last longer in these countries.

The estimates of the PSECM terms are given below.

All Countries:

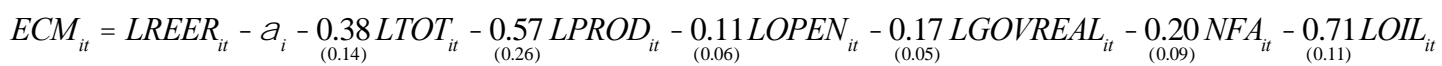

Higher Income Countries:

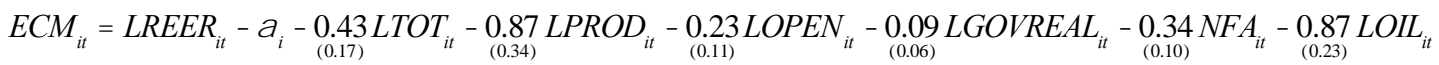


Lower Income Countries:

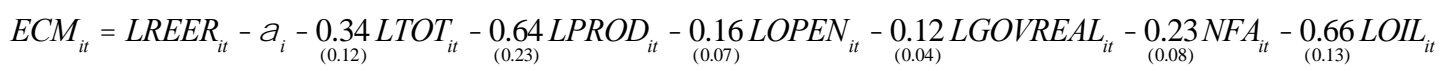

Oil and Gas Exporters:

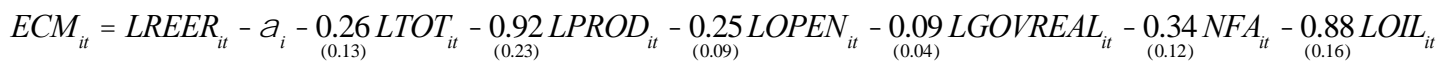

Non- Oil and Gas Exporters:

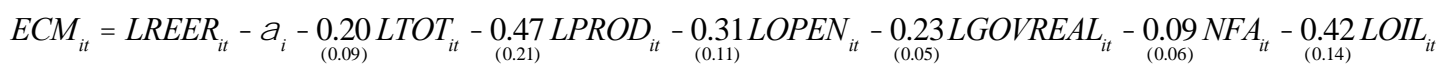

where the numbers in parentheses are standard errors. We notice that almost all the estimates are statistically significant and long-term equilibrium estimates of the parameters all have expects theoretical sign. Government expenditures have an insignificant coefficient for higher income countries. Interestingly, real oil price increases appreciates the domestic currency, supporting the Dutch disease phenomena, but more for the oil and gas exporting countries. Oil price increases also appreciate the real exchange rate in non- oil and gas exporting countries, implying that there is contagion effect due to very strong economies ties between these countries arising from geographic and historical proximity. According to estimates given in Equation (7d) one percent increase (decrease) in real oil price leads to approximately 0.88 percent appreciation (depreciation) of real effective exchange rate in oil and gas exporting countries.

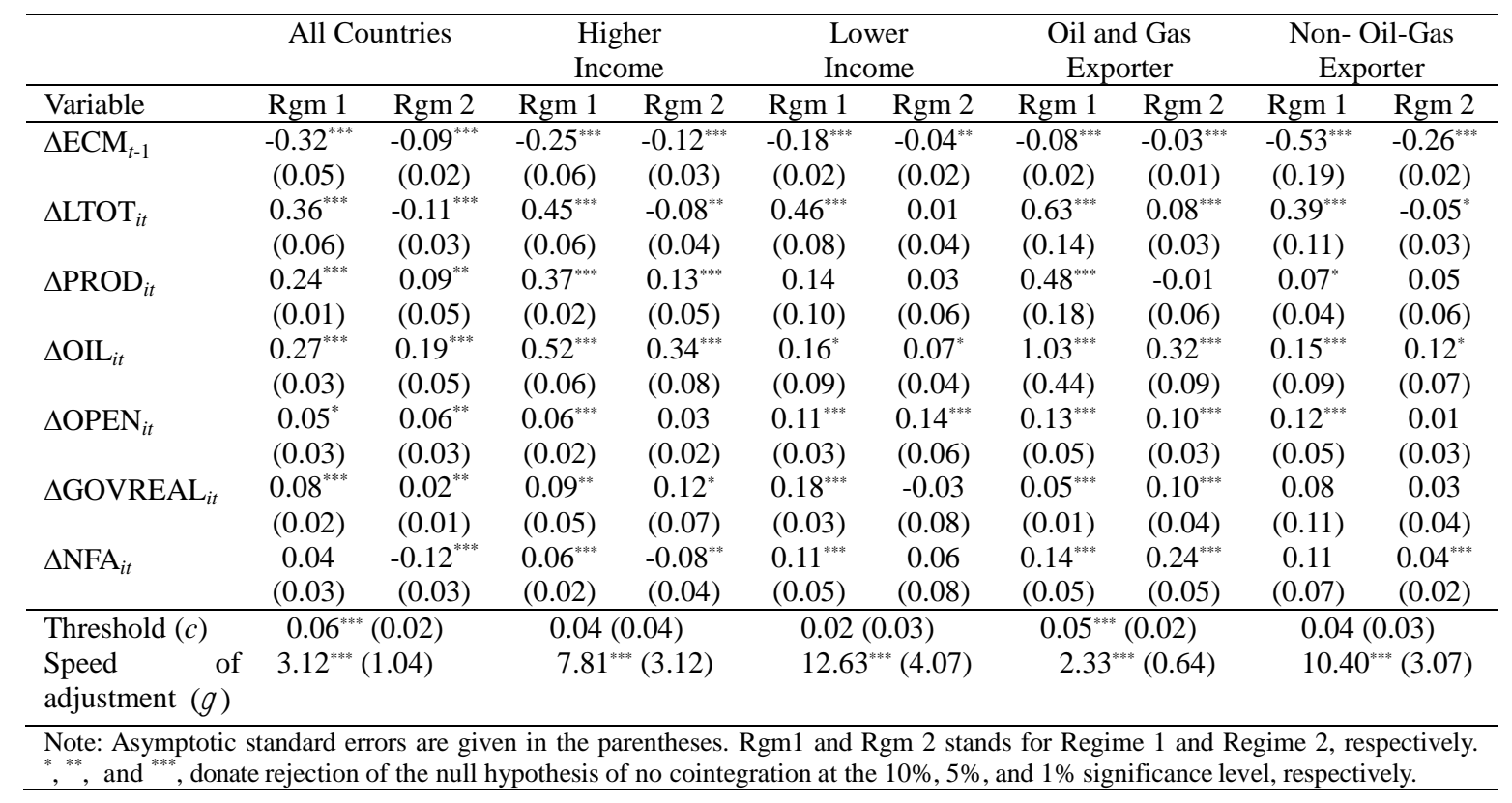

Table 4. Panel Smooth Transitions Error Correction Model Estimation Results

\section{Conclusion}

While the stable long-run relationship between real exchange rate and fundamental macroeconomic variables, suitably defined for transition and emerging economies, may serve as a guideline for exchange rate policy, the short-run dynamics is also crucial to policy-makers in determining the timing and extent of a potential intervention. Therefore, it is crucial to specify a model that captures the short run adjustment to the equilibrium properly. To this end, this paper investigated adjustment process of real effective exchange rates towards their equilibrium levels in selected CIS countries, by estimating an error correction model in panel data and further allowing nonlinear adjustment. Study reveals that real oil price has statistically significant and positive effect on real effective exchange rate of the CIS countries, which is in support of the findings for oil-exporting countries. There are three important implications of the findings of this paper. First, the paper finds that oil price plays a significant role both in determining the long-run equilibrium level and in the short-run adjustment process of the real exchange rate. Therefore, the findings of the study points possibility of Dutch Disease phenomena, for at least the oil-exporting CIS countries. Second, the adjustment process of the real exchange rate towards its equilibrium is clearly nonlinear and policy makers should be aware that the adjustment process is different during periods of appreciations and depreciations. Third, the direction of the causality seems to be from real oil price to the exchange rate, implying that the policies should not concentrate on foreign exchange rates in the face of an oil price shock as they will most likely to fail. 


\section{References}

- Akram, Q. Farooq. (2004), "Oil prices and exchange rates: Norwegian evidence”, Econometrics Journal, 7:476-504.

- Amano, Robert. A. and van Norden, Simon. (1998)," Oil prices and the rise and fall of the US real exchange rate", Journal of International Money and Finance, 2(17):299-316.

- Bergvall, Anders. (2004), "What determines real exchange rate? The Nordic Countries", The Scandinavian Journal of Economics, 106(2):315-337.

- Brown, Stephen P.A., Philips, Keith Richard (1986), “Exchange rates and World oil prices”, Economic Review, 0(0):1 10.

- Bruno, M. and J. Sachs (1982). Energy and Resource Allocation: A Dynamic Model of the Dutch Disease. Review of Economic Studies, 49 (5), 845-59.

- $\quad$ Buiter, W. and D. Purvis (1983). Oil, Disinflation and Export Competitiveness: A Model of the Dutch Disease. National Bureau of Economic Research Working Paper 592 (Cambridge, Mass: NBER).

- Chaudhuri, Kausik. and Daniel, Betty. C. (1998),"Long-run equilibrium real exchange rates and oil prices”, Economics Letters, 58:231-238.

- Chen, S.-S. and Chen, H.-C. (2007), “Oil prices and real exchange rates”, Energy Economics, 29(3):390-404.

- Cooper, Ronald. (1994), "Changes in exchange rates and oil prices for Saudi Arabia and other Opec members", The journal of Energy and Development, 20(1):109.

- Corden, W.M., (1984). Booming Sector and Dutch Disease Economics: Survey and Consolidation. Oxford Economic Papers 36, 359-380.

- $\quad$ Corden, W.M. and J.P.Neary (1982). Booming Sector and De-Industrialization in a Small Open Economy. Economic Journal 92, 825-848.

- $\quad$ Edwards, S. (1985). A commodity export boom and the real exchange rate: the money-inflation link. NBER Working Paper Series, Working Paper No. 1741.

- $\quad$ Edwards, S. (1994) "Real and monetary determinants of real exchange rate behavior: Theory and evidence from developing countries", in J. Willimason (ed.), Estimating Equilibrium Exchange Rates, Washington: Institute for International Economics.

- Elbadawi, I. (1994) “Estimating Long Run Real Exchange Rates”, in J. Williamson (ed.), Estimating Equilibrium Exchange Rates, Washington: Institute for International Economics.

- $\quad$ Enders, K. and H.Herberg (1983). The Dutch Disease: Causes, Consequences, Cure and Calmatives. Welwirtschaftliches Archiv 119, 3, 473-9.

- Habib, M. and M. Kalamova (December 2007). Are there oil currencies? The real exchange rate of oil exporting countries. European Central Bank, Working Paper Series No 839.

- Hinkle, L. and P. Montiel (1999) Exchange Rate Misalignment: Concepts and Measurement for Developing Countries, Oxford: Oxford University Press.

- Issa, R. and R. Lafrance, and J.Murray, (2006). The Turning Black Tide: Energy Prices and the Canadian Dollar. Working Paper 2006-29, Bank of Canada, Ottawa.

- Jahan-Parvar, M. and H. Mohammadi (2008). Oil Prices and Real Exchange Rates in Oil-Exporting Countries: A Bounds Testing Approach. Illinois State University, Normal, East Carolina University, 28.

- Krichene, N. (2005),"A Simultaneous equation model for World crude oil and natural gas markets", IMF working paper.

- Koranchelian, T. (2005). The equilibrium real exchange rate in a commodity exporting country: Algeria's experience. IMF Working Paper 05/135, Washington D.C.

- Korhonen, I. and T. Juurikkala (2009). Equilibrium Exchange Rates in Oil Exporting Countries. Journal of Economics and Finance 33 (1), p.71-79.

- Korhonen, Likka., Mehrotra, Aaron. (2009), "Real exchange rate, output and oil: case of four large energy producers", Bank of Finland Institute for Economies in Transition (BOFIT) discussion papers 6

- $\quad$ Oomes, N. and K. Kalcheva (2007). Diagnosing Dutch Disease: Does Russia Have the Symptoms. BOFIT Discussion Paper No 6.

- Rautava J. (2004), “The role of oil prices and the real exchange rate in Russia's economy-Cointegration approach", Journal of Comparative Economics, 32(2):315.

- Wijnbergen, S.V. (1984). Inflation, Employment, and the Dutch Disease in Oil-Exporting Countries: A Short Run Disequilibrium Analysis. The Quarterly Journal of Economics, Vol. 99, No. 2 pp. 233-250.

- Zalduendo, J. (2006). Determinants of Venezuela's equilibrium real exchange rate. IMF Working Paper 06/74, Washington D.C. 